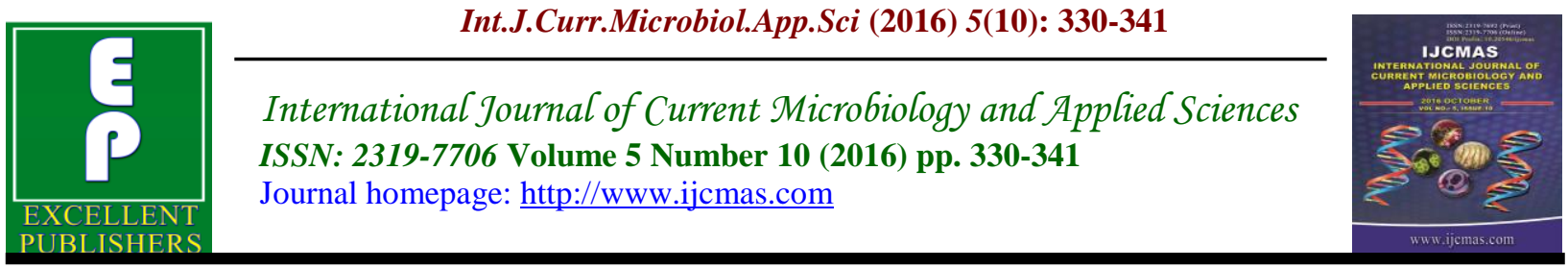

Original Research Article

http://dx.doi.org/10.20546/ijcmas.2016.510.037

\title{
Detection and Identification of Hepatitis B, C and HIV in Benghazi city, Libya
}

\author{
Hanan I. Abdalla IL Fergani ${ }^{1 *}$ and Ismaeel H. Bozakouk ${ }^{1,2}$ \\ ${ }^{1}$ Microbiology, Botany Department, Faculty of Science, University of Benghazi, Libya \\ ${ }^{2}$ Microbiology Department, Al Razi medical Centre, Benghazi, Libya \\ *Corresponding author
}

\section{Keywords}

Hepatitis B, C and HIV, hepatocellular carcinoma.

Article Info

Accepted:

14 September 2016

Available Online:

10 October 2016

\section{A B S T R A C T}

Libya is one of the largest countries in Africa and has the longest coast in the Mediterranean basin facing southern Europe. High rates of prevalence of viral hepatitis and HIV infection have been observed in various regions in Africa, however, prevalence of hepatitis B, C and HIV infection in Benghazi, Libya is not well documented. This study was designed to detect and identify the hepatitis viruses $\mathrm{B}, \mathrm{C}$ and HIV among community in Benghazi city. In this study, we focused on three human resources including adult Libyan nationals, Libyan children and foreigner workers. Also as a selective sources representing the majority of serology referencing including four medical centre are a privet laboratory is Al Razi medical Centre and three governmental medical centers including Benghazi Centre of infectious diseases, Children hospital, and the medical Laboratory of Red crescent centre. Benghazi, Libya. In this study, we identified the extent of the viral infection at the local level, where the samples included 800 patients represented of all age groups with 200 samples from each source. The results showed that, the infection with HBV surface antigen (HBsAg) and HCV were $(6.4 \%)$ and $(5 \%)$ respectively and HIV virus was (1.9\%). The prevalence of $\mathrm{HCV}$ increased with age, in contrast the prevalence of $\mathrm{HBs} \mathrm{Ag}$ and HIV infection are common in young people. From this study, we concluded that infection with HBV, HCV, and HIV areobvious problem in Libya. A communitybased study should be planned for targeting at risk and non-at risk subjects to investigate the extent of this problem and its impact on the community with an effort to develop preventive strategies.

\section{Introduction}

\section{Background}

Hepatitis B virus (HBV), hepatitis $\mathrm{C}$ virus (HCV), and HIV infections represent a global public health problem. Transmission of these viruses occurs via blood and blood products transfusion and by sexual contact (Lee et al., 2001). Regards HBV much has been learned about it since its original discovery in 1965. Leading to the availability of hepatitis B vaccine for the prevention of the disease and multiple drugs for the treatment of its chronic status. Chronic HBV infection is a global major public health problem. Its prevalence and patterns of transmission vary greatly 
throughout the world. Approximately, two billion individuals worldwide have been infected with HBV and between 350 and 400 million persons have chronic HBV infection. Individuals who have chronic HBV infection from birth have $15 \%$ to $30 \%$ lifetime risk for developing cirrhosis associated with hepatic decompensation and/or hepatocellular carcinoma, leading to premature death (Blumberg et al., 1965; Lavnchy, 2004 and Keeffe, 2007). The hepatitis B surface antigen (HBsAg) in serum is the first seromarker to indicate active HBV infection, either acute or chronic. A hepatitis B vaccine, available since 1982, has a high efficacy in the prevention of $\mathrm{HBV}$ transmission and has brought about remarkable changes in the global epidemiology of HBV infection (Lok and Mcmahon, 2007; Sood and Malvankar, 2010).

The endemicity of HBV infection varies greatly over the world, from highly endemic areas (> $8 \%$ infection rate), to intermediate $(2-8 \%)$ and low endemicity areas $(<2 \%)$. Africa is among the highly endemic areas, but some countries in the north fall in the intermediate category, with an average rate of about $7 \%$, whereas most regions of west and east Africa are highly endemic areas with chronic infection rates of $7-10 \%$ (Lavanchy, 2004). African countries have among the highest prevalence rates of $\mathrm{HCV}$ in the world, ranging from one to $26 \%$ (WHO, 1999; Muhlberger et al., 2009). More than 28 million people are chronically infected with HCV in this continent, and it is difficult to speculate about current and future trends (Daw, 2012; Abdelwahab et al., 2013). Libya, a developing country of approximately 6 million people, belongs to the intermediate endemicity countries (Daw et al., 2002; Elzouki, 2008). HCV infection is also common worldwide; it is transmitted in a manner similar to HBV (WHO, 2009). Hepatitis $\mathrm{C}$ virus has been considered one of the most potential pathogens that have hindered the medical community all over the world. Indeed, since its discovery in 1989, hepatitis $\mathrm{C}$ virus (HCV) has been recognized as a major cause of chronic liver disease worldwide (Shepard et al., 2005). More than 170 million people are chronically infected with hepatitis $\mathrm{C}$ virus (HCV) worldwide (WHO, 2010) the data reported by WHO estimated that the prevalence of $\mathrm{HCV}$ infection is $2.2 \%$, and more than one million new cases were reported annually. Furthermore, an estimated $27 \%$ of cirrhosis and $25 \%$ of hepato-cellular carcinomas (HCC) worldwide occur in $\mathrm{HCV}$-infected people.

Such infection increases tremendously among the developing countries particularly at those categories that were considered to be at a potential risk of acquiring hepatitis $\mathrm{C}$ virus (Alter, 2007). As well, the global impact of the HIV and AIDS epidemic has spurred its rapid prioritization as one of the most pressing health issues facing the world community. While the epidemiology and social forces affecting its continued proliferation differ between communities and regions, HIV has spread worldwide. In 2012, an estimated 35.3 million people around the world were living with HIV and AIDS and 2.3 million were newly infected with the virus. Of those affected by HIV, young people around the world assume a disproportionate burden of the disease, with $40 \%$ of new cases of HIV infection occurring amongst them (Abu-Raddad et al., 2010 and Abu-Raddad et al., 2010). Recent data on the prevalence of hepatitis B and C and HIV viruses and risk factors among the Libyan population are lacking. Such data are important for understanding the burden of viral infection and for predicting future trends. Implementation of surveillance to guide public health policy is needed to efficiently control viral hepatitis spread in Libya, and this requires reliable 
epidemiological data (Bagasra et al., 2007; Daw and Elkhammas, 2008). Most of the epidemiological studies carried out individually based upon seroprevalence of $\mathrm{HCV}$ among specific groups. These include blood donors, heath care workers, or patients undergoing haemodialysis. Such studies were not representative of the community; independent scientists usually carried them out, even though some countries lack such studies (Sievert et al., 2011).

\section{Methods}

This study was designed to identify the prevalence of hepatitis viruses B, C and HIV in Benghazi city. In this study, we focused on three human resources including adult Libyan community, Libyan children and foreigner workers. Also as a selective sources representing the majority of serology referencing including four medical centre are a privet laboratory is Al Razi Medical Centre and three governmental medical centers including Benghazi Centre of infectious diseases, Children hospital, and the medical Laboratory of Red crescent centre. Benghazi, Libya. People who are chosen for virology analysis were selected based on their medical history as well as by a referral from a medical consultation to the serology department. In addition to that, all cases of blood drawing were applied as a response to the desire of the patients, not a voluntary programmed, nor a study to Libyan health organizations.

Libyan adult's samples were tested in $\mathrm{Al}$ Razi Medical Centre, all children's blood samples were collected and analyzed in children hospital. People who have medical history of the disease were tested in the Benghazi medical centre of infectious diseases, and blood samples collection, virology investigation of the foreigner worker were carried out in the medical centre of Benghazi Red crescent. All blood samples were collected in accordance with a standard medical technique. In order to obtain blood serum, all whole blood samples were collected in covered clean test tubes, the blood samples were allowed to clot by leaving them undisturbed at room temperature for 15-30 minutes, tubes were then centrifuged (5000 rpm for 10 minutes), the resulting supernatant is serum. Following centrifugation, immediately serum components were transferred in to a clean polypropylene tubes using a Pasteur pipettes, serum samples were maintained at $2-8 \mathrm{C}^{\circ}$ prior analyzing. If serum is not analyzed immediately, serum should be stored at $-20 \mathrm{C}^{\circ}$. It is important to avoid serum components destructive by not use freeze-thaw cycles if so mix thawed samples thoroughly by low speed overtaxing 10 times, visually inspect the samples, if layering or stratification is observed, continue mixing until samples are visibly homogeneous. After thawing, bring to room temperature and mix well by gently shaking.

\section{Identification Method}

Enzyme Linked Immuno Sorbent Assay (ELISA test) and Polymerase Chain Reaction (PCR test) It was used HBsAg ELISA version (1) Kit and HCV ELISA version (1) Kit and HIV ELISA version (1) Kit manufacturer (Germany).

\section{Storage Conditions}

Most of serum samples were examined for viral infection directly after samples collection, for short time storage less than 8 hours, serum samples were stored between $18-25 \mathrm{C}^{\circ}$. For longer time storage up to 48 hours, samples were stored at $2-8 \mathrm{C}^{\circ}$. For long time storage, more than 48 hours, serum samples were stored at $-20 \mathrm{C}^{\circ}$. 


\section{Results and Discussion}

\section{Distribution of $\mathrm{HBV}$ among patients according to the age and gender}

This analysis was including the collection of samples from four sources. 800 was the total of the random samples. The distribution of included for 0-13, 14-45 and 46-80 years. In age $0-13$ total of samples male and female was 225,3 male and two female have shown infection with $\mathrm{HBV}$ with total percentage $(2.2 \%)$. In age of 14-45, total of sample was 496, 21 male and 21 female are infected with $\mathrm{HBV}$, total percentage ( $8.5 \%)$. In age of 46-80, total of samples was 79 , the number of patients are infected with $\mathrm{HBV}$ are 2 in male and 2 in female with total percentage $(5 \%)$ respectively. People with age 14-45 showed the highest percentage of infection with $\mathrm{HBV}(8.5 \%)$, P-value = 0.005 , table (1).

\section{Distribution of HBV infection according to source of samples and age}

800 is the total of samples from four different sources, 200 sample each was included in this section. In the private laboratory, age of 0-13 no patients have attended to the laboratory driving this study, in age 14-45, 170 are representing the total samples and the result showed that 34 patients have infect with HBV (20\%), in age $46-80,30$ are the total of samples, with the recorded of infection is 3 patients (10\%). In children hospital only age of $0-13$ showed patients participated to the hospital, 5 patients infected with the virus $(2.5 \%)$. The results obtained from Red Crescent medical laboratory, showed that age 14-45, 183 are total of patients, one $(0.5 \%)$ patient has infected with the virus, non-in the other age. Results of Center of infectious diseases revealed in age 14-45 the total samples are 143 where $7(4.9 \%)$ patients are infected with virus, in age 46-80, 34 patients have attended to the center one patient $(2.9 \%)$ was recorded with infection, non-results in age $0-13$. private laboratory showed the highest rates to infection for all ages where the ratio of $\mathrm{HBV} 18.5 \%, \mathrm{P}$-value $=0.000$, table (1).

\section{Distribution of HBV infection according to source of samples and gender}

In private laboratory total of samples male and female was 200 where 19 male and 18 female have shown infection with $\mathrm{HBV}$ with total percentage $(18.5 \%)$. In children hospital total of samples was 200, 3 male and 2 female are infected with HBV with total percentage $(2.5 \%)$. In red crescent laboratory total of samples was 200, only one person (male) is infected with $\mathrm{HBV}$ with total percentage $(0.5 \%)$, in Center of infectious diseases total of samples was 200 , the number of patients are infected with $\mathrm{HBV}$ are 3 in male and 5 in female with total percentage $(4 \%)$. Although the rate of infection in all sources with exception Center of infectious diseases was highest in male than female, however the table ratio of infection with HBV was more in female than in all sources, with total percentage of female $7 \%$, p-value $=0.562$ while in male $5.9 \%$, table (1).

\section{Distribution of $\mathrm{HCV}$ among patients according to the age and gender}

In age 0-13 total of samples male and female was 225, 2 male and 5 female have shown infection with $\mathrm{HCV}$ with total percentage $(3.1 \%)$. In age of 14-45 total of samples was 496, 11 male and 8 female are infected with $\mathrm{HCV}$ with total percentage $(3.8 \%)$. in age of $45-80$ years total of samples was 79 , the number of patients are infected with $\mathrm{HCV}$ are 5 in male and 9 in female with total percentage (17.7\%). People with age 46-80 
years showed the highest percentage of infection with $\mathrm{HCV}$ virus (17.7\%), P-value $=0.000$, table $(2)$.

\section{Distribution of $\mathrm{HCV}$ infection according to source of samples and age}

In the private laboratory, age of $0-13$ no patients have attended to the laboratory driving this study, in age 14-45, 170 are representing the total samples and the result showed that 14 patients have infect with HCV (8.2\%). In age 46-80, 30 are the total of samples, with the recorded of infection is 8 patients $(26.7 \%)$. In children hospital only age of $0-13$ showed patients participated to the hospital, 7 patients infected with the virus (3.5\%). Red Crescent medical laboratory it did not recorded any infection with $\mathrm{HCV}$ virus for all ages.

The results obtained from Center of infectious diseases, showed that age 14-45 the total samples are 143 where $5(3.5 \%)$ patients are infected with virus, in age 46-80 years 34 patients have attended to the center $6(17.6 \%)$ was recorded with infection, nonresults in age 0-13. Private laboratory showed the highest rates to infection for all ages where the ratio of $\mathrm{HCV} 11 \%, \mathrm{P}$-value $=$ 0.000 , table (2).

\section{Distribution of $\mathrm{HCV}$ infection according to source of samples and gender}

In private laboratory total of samples male and female was 200 where 11 male and 11 female have shown infection with $\mathrm{HCV}$ with total percentage (11\%). In children hospital total of samples was 200, 2 male and 5 female are infected with HCV (3.5\%). In Red Crescent laboratory from total of samples did not recorded any infection with $\mathrm{HCV}$ virus. In Center of infectious diseases total of samples was 200, the number of patients are infected with $\mathrm{HCV}$ virus are 5 male and 6 female with total percentage (5.5\%). The rate of infection with $\mathrm{HCV}$ virus was more in female than male in all sources. The total percentage of female infected with HCV in all sources was $6.1 \%$, $\mathrm{p}$-value $=0.195$. While was $4.1 \%$ in male, table (2).

\section{Distribution of HIV among patients according to the age and gender}

In age 0-13 years total of samples male and female was 225,2 male and 1 female have shown infection with HIV with total percentage $(1.3 \%)$. in age of 14-45 years total of samples was 496, 7 male and 5 female are infected with HIV with total percentage $(2.4 \%)$. In age of $46-80,79$ are total of patients, one female $(1.3 \%)$ has infected with the virus. People with age 1445 years showed the highest percentage of infection with HIV virus $(2.4 \%)$, p-value $=$ 0.653 , table (3).

\section{Distribution of HIV infection according to source of samples and age}

In the private laboratory, age of $0-13$ no patients have attended to the laboratory driving this study, in age 14-45, 170 are representing the total samples and the result showed that 6 patients have infect with HIV $(3.5 \%)$. in age $46-80,30$ are the total of samples with the recorded of infection is 1 patient (3.3\%). In children, hospital and Red Crescent laboratory are not recorded any infection with HIV virus.

Results of Center of infectious diseases revealed in age $0-13$ the total samples are 23 where $3(13 \%)$ patients are infected with virus, in age 14-45 years 143 patients have attended to the center $6(4.2 \%)$ patients was recorded with infection, non-results in age 46-80. Communicable disease center showed the highest rates to infection for all 
ages where the ratio of HIV (4.5\%), p-value $=0.001$, Table $(3)$.

\section{Distribution of HIV infection according to source of samples and gender}

In a private laboratory total of samples male and female was 200 where 3 male and 4 female have shown infection with HIV with total percentage (3.5\%). In children, hospital and Red Crescent laboratory are not recorded any infection with HIV virus. In Center of infectious diseases total of samples was 200, the number of patients are infected with HIV virus are 6 male and 3 female with total percentage $(4.5 \%)$. The ratio of infection with HIV virus was in male $2 \%$, p-value $=1.000$ while the percentage in female $1.95 \%$ in all sources. Table (3)

\section{PCR Results}

In the Center of infectious diseases, serum samples were assured for PCR technology and the results were as follow: It has been assured six samples infected with hepatitis B virus and the result was $100 \%$ confirmed. It has been assured six samples infected with hepatitis $\mathrm{C}$ virus and the result was 50\% confirmed. It has been assured three samples infected with HIV virus and the result was $100 \%$ confirmed.

Our study demonstrated that, the infection of $\mathrm{HBV}, \mathrm{HCV}$, and HIV is rare but may increase the risk of progression of chronic liver disease. This study has found that the seroprevalence of HBsAg among patients is $6.4 \%, 5 \%$ in $\mathrm{HCV}$ and $1.9 \%$ in HIV. In the same study In the Central Hospital in Tripoli, Libya screened between January 2005 and December 2008 the finding of this study indicated that the seroprevalenceof HBsAg was $12.8 \%$, was in HCV $6.9 \%$ and HIV was $0.9 \%$ (Khammaj et al ., 2010).
Also in Libya, (Zaied et al., 2010) reported frequency rates of $0.4,2.6$, and $3 \%$ for antiHIV antibodies, HBs-Ag, and anti-HCV antibodies, respectively, which were also reported by (Habas et al., 2009) and (Abudher et al., 2008). Few studies of the prevalence of hepatitis B, C and HIV viruses in Libya explaining viral endemicity and examined specific distribution among population such as children, adults, foreigner workers even genotype (Daw et al., 2014). The epidemiology of these diseases in Europe most of African countries is well studies , Libya classified as the lowest endemicity countries along with European Mediterranean countries, Tunisia, Algeria, Morocco, Egypt, Chad, Sudan and Niger (Daw et al., 2014). In Libya vaccination against $\mathrm{HBV}, \mathrm{HCV}$ and $\mathrm{HIV}$ infections has been offered free of charge and become compulsory since 1991 for fants and for children up to age of 12 years, these restrictions and early efforts were adopted by National Prevention program of infection diseases in Libya. In Libya a study was carried out on prevalence of hepatitis B and C infections 2014 showed that the rate of infection was varied from one region to another in both viruses, where they found in Benghazi city is classified as the one of the lowest rate of infection over all Libyan cities, the rate of HBV prevalence was significantly higher in male than females, so the rate of $\mathrm{HCV}$ infection among male and females were similar (Daw et al., 2014). However, this contrasting with the results we obtained, where the rate of $\mathrm{HBV}, \mathrm{HCV}$ and HIV infection in females were higher than males especially in adults. The prevalence of HBV in group age of 14-45 was significantly higher than group age of $45-80(8.5 \%)$, in contrast the prevalence of $\mathrm{HCV}$ showed the rate of incidence is increased with the age (17.7\%) (P-value= 0.000 ), this were similar results to studies in Libya, including a study carried out by Daw 
et al., 2014 and a study by Kutrani et al., 2007 and Elzouki et al., 2012 and a study in Morocco carried out by Baha et al., 2013. While the HIV disease were more rate in age 14-45 (2.2\%). In Libya, most of the blood donors are young men (20_40 years of age). It is known that this age group is usually in the high-risk for drug abuse, sexual activity
(Libyan, 2010). Our study was carried out on prevalence of $\mathrm{HBV}$, $\mathrm{HCV}$, HIV viruses among the foreigner workers in both males and females were underwent mandatory test pre-employment as well as in children before study, we found that between 200 samples only one case reported with HBV was from Chad.

Table.1 Distribution of HBV among Patients according to the (age and gender), (source of samples and age), (source of samples and gender)

\begin{tabular}{|c|c|c|c|c|}
\hline Age & Gender & Negative & Positive & Total \\
\hline $0-13$ & $\begin{array}{l}\text { Male } \\
\text { Female }\end{array}$ & $\begin{array}{l}121(97.6 \%) \\
99(98.01 \%)\end{array}$ & $\begin{array}{l}3(2.4 \%) \\
2(1.98 \%)\end{array}$ & $\begin{array}{l}124 \\
101\end{array}$ \\
\hline $14-45$ & $\begin{array}{l}\text { Male } \\
\text { Female }\end{array}$ & $\begin{array}{l}253(92.3 \%) \\
201(90.5 \%)\end{array}$ & $\begin{array}{l}21(7.7 \%) \\
21(9.5 \%)\end{array}$ & $\begin{array}{l}274 \\
222\end{array}$ \\
\hline $46-80$ & $\begin{array}{l}\text { Male } \\
\text { Female }\end{array}$ & $\begin{array}{ll}41 & (95.3 \%) \\
34 & (94.4 \%)\end{array}$ & $\begin{array}{l}2(4.7 \%) \\
2(5.6 \%)\end{array}$ & $\begin{array}{l}43 \\
36\end{array}$ \\
\hline Source & Age & Negative & Positive & Total \\
\hline Private lab & \begin{tabular}{l|}
$0-13$ \\
$14-45$ \\
$46-80$ \\
\end{tabular} & $\begin{array}{l}0(0 \%) \\
136(80 \%) \\
27(90 \%)\end{array}$ & $\begin{array}{l}0(0 \%) \\
34(20 \%) \\
3(10 \%)\end{array}$ & $\begin{array}{l}0 \\
170 \\
30 \\
\end{array}$ \\
\hline $\begin{array}{l}\text { Children } \\
\text { hospital }\end{array}$ & $\begin{array}{l}0-13 \\
14-45 \\
46-80 \\
\end{array}$ & $\begin{array}{l}195(97.5 \%) \\
0(0 \%) \\
0(0 \%)\end{array}$ & $\begin{array}{l}5(2.5 \%) \\
0(0 \%) \\
0(0 \%)\end{array}$ & $\begin{array}{l}200 \\
0 \\
0 \\
\end{array}$ \\
\hline Red crescent & $\begin{array}{l}0-13 \\
14-45 \\
46-80\end{array}$ & $\begin{array}{l}2(100 \%) \\
182(99.5 \%) \\
15(100 \%)\end{array}$ & $\begin{array}{l}0(0 \%) \\
1(0.5 \%) \\
0(0 \%)\end{array}$ & $\begin{array}{l}2 \\
183 \\
15\end{array}$ \\
\hline $\begin{array}{l}\text { Center of } \\
\text { infectious } \\
\text { diseases }\end{array}$ & $\begin{array}{l}0-13 \\
14-45 \\
46-80 \\
\end{array}$ & $\begin{array}{l}23(100 \%) \\
136(95.1 \%) \\
33(97.1 \%)\end{array}$ & $\begin{array}{l}0(0 \%) \\
7(4.9 \%) \\
1(2.9 \%) \\
\end{array}$ & $\begin{array}{l}23 \\
143 \\
34 \\
\end{array}$ \\
\hline Source & Gender & Negative & Positive & Total \\
\hline Private lab & $\begin{array}{l}\text { Male } \\
\text { Female }\end{array}$ & $\begin{array}{l}64(77.1 \%) \\
99(84.6 \%)\end{array}$ & $\begin{array}{l}19(22.9 \%) \\
18(15.4 \%)\end{array}$ & $\begin{array}{l}83 \\
117\end{array}$ \\
\hline $\begin{array}{l}\text { Children } \\
\text { hospital }\end{array}$ & $\begin{array}{l}\text { Male } \\
\text { Female }\end{array}$ & $\begin{array}{l}105(97.2 \%) \\
90(97.8 \%)\end{array}$ & $\begin{array}{l}3(2.8 \%) \\
2(2.2 \%)\end{array}$ & $\begin{array}{l}108 \\
92\end{array}$ \\
\hline Red crescent & $\begin{array}{l}\text { Male } \\
\text { Female }\end{array}$ & $\begin{array}{l}158(99.4 \%) \\
41(100 \%)\end{array}$ & $\begin{array}{l}1(0.62 \%) \\
0(0 \%)\end{array}$ & $\begin{array}{l}159 \\
41\end{array}$ \\
\hline $\begin{array}{l}\text { Center of } \\
\text { infectious } \\
\text { diseases }\end{array}$ & $\begin{array}{l}\text { Male } \\
\text { Female }\end{array}$ & $\begin{array}{l}89(96.7 \%) \\
103(95.4 \%)\end{array}$ & $\begin{array}{l}3(3.3 \%) \\
5(4.6 \%)\end{array}$ & $\begin{array}{l}92 \\
108\end{array}$ \\
\hline
\end{tabular}


Table.2 Distribution of HCV among Patients according to the age and gender (source of samples and age), (source of samples and gender)

\begin{tabular}{|c|c|c|c|c|}
\hline Age & Gender & Negative & Positive & Total \\
\hline $0-13$ & $\begin{array}{l}\text { Male } \\
\text { Female }\end{array}$ & $\begin{array}{l}122(98.4 \%) \\
96(95 \%)\end{array}$ & $\begin{array}{l}2(1.6 \%) \\
5(5 \%)\end{array}$ & $\begin{array}{l}124 \\
101\end{array}$ \\
\hline $14-45$ & $\begin{array}{l}\text { Male } \\
\text { Female }\end{array}$ & $\begin{array}{l}264(96 \%) \\
213(96.4 \%)\end{array}$ & $\begin{array}{l}11(4 \%) \\
8(3.6 \%)\end{array}$ & $\begin{array}{l}275 \\
221\end{array}$ \\
\hline 46-80 & $\begin{array}{l}\text { Male } \\
\text { Female }\end{array}$ & $\begin{array}{ll}38 & (88.4 \%) \\
27 & (75 \%)\end{array}$ & $\begin{array}{l}5(11.6 \%) \\
9(25 \%)\end{array}$ & $\begin{array}{l}43 \\
36\end{array}$ \\
\hline Source & Age & Negative & Positive & Total \\
\hline Private lab & $\begin{array}{l}0-13 \\
14-45 \\
46-80\end{array}$ & $\begin{array}{l}0(0 \%) \\
156(91.8 \%) \\
22(73.3 \%)\end{array}$ & $\begin{array}{l}0(0 \%) \\
14(8.2 \%) \\
8(26.7 \%)\end{array}$ & $\begin{array}{l}0 \\
170 \\
30\end{array}$ \\
\hline $\begin{array}{l}\text { Children } \\
\text { hospital }\end{array}$ & $\begin{array}{l}0-13 \\
14-45 \\
46-80 \\
\end{array}$ & $\begin{array}{l}193(96.5 \%) \\
0(0 \%) \\
0(0 \%)\end{array}$ & $\begin{array}{l}7(3.5 \%) \\
0(0 \%) \\
0(0 \%)\end{array}$ & $\begin{array}{l}200 \\
0 \\
0\end{array}$ \\
\hline Red crescent & $\begin{array}{l}0-13 \\
14-45 \\
46-80\end{array}$ & $\begin{array}{l}2(100 \%) \\
183(100 \%) \\
15(100 \%)\end{array}$ & $\begin{array}{l}0(0 \%) \\
0(0 \%) \\
0(0 \%)\end{array}$ & $\begin{array}{l}2 \\
183 \\
15\end{array}$ \\
\hline $\begin{array}{l}\text { Center of } \\
\text { infectious } \\
\text { diseases }\end{array}$ & $\begin{array}{l}0-13 \\
14-45 \\
46-80\end{array}$ & $\begin{array}{l}23(100 \%) \\
138(96.5 \%) \\
28(82.4 \%)\end{array}$ & $\begin{array}{l}0(0 \%) \\
5(3.5 \%) \\
6(17.6 \%)\end{array}$ & $\begin{array}{l}23 \\
143 \\
34\end{array}$ \\
\hline Source & Gender & Negative & Positive & Total \\
\hline Private lab & $\begin{array}{l}\text { Male } \\
\text { Female }\end{array}$ & $\begin{array}{l}72(86.7 \%) \\
106(90.6 \%)\end{array}$ & $\begin{array}{l}11(13.3 \%) \\
11(9.4 \%)\end{array}$ & $\begin{array}{l}83 \\
117\end{array}$ \\
\hline $\begin{array}{l}\text { Children } \\
\text { hospital }\end{array}$ & $\begin{array}{l}\text { Male } \\
\text { Female }\end{array}$ & $\begin{array}{l}106(98.1 \%) \\
87(94.6 \%)\end{array}$ & $\begin{array}{l}2(1.9 \%) \\
5(5.4 \%)\end{array}$ & $\begin{array}{l}108 \\
92\end{array}$ \\
\hline Red crescent & $\begin{array}{l}\text { Male } \\
\text { Female }\end{array}$ & $\begin{array}{l}159(100 \%) \\
41(100 \%)\end{array}$ & $\begin{array}{l}0(0 \%) \\
0(0 \%)\end{array}$ & $\begin{array}{l}159 \\
41\end{array}$ \\
\hline $\begin{array}{l}\text { Center of } \\
\text { infectious } \\
\text { diseases }\end{array}$ & $\begin{array}{l}\text { Male } \\
\text { Female }\end{array}$ & $\begin{array}{l}87(94.6 \%) \\
102(94.4 \%)\end{array}$ & $\begin{array}{l}5(5.4 \%) \\
6(5.6 \%)\end{array}$ & $\begin{array}{l}92 \\
108\end{array}$ \\
\hline
\end{tabular}


Table.3 Distribution of HIV among Patients according to the (age and gender), (source of samples and age), (source of samples and gender)

\begin{tabular}{|c|c|c|c|c|}
\hline Age & Gender & Negative & Positive & Total \\
\hline $0-13$ & $\begin{array}{l}\text { Male } \\
\text { Female }\end{array}$ & $\begin{array}{l}122(98.4 \%) \\
100(99 \%)\end{array}$ & $\begin{array}{l}2(1.6 \%) \\
1(1 \%)\end{array}$ & $\begin{array}{l}124 \\
101\end{array}$ \\
\hline $14-45$ & $\begin{array}{l}\text { Male } \\
\text { Female }\end{array}$ & $\begin{array}{l}269(97.5 \%) \\
215(97.7 \%)\end{array}$ & $\begin{array}{l}7(2.5 \%) \\
5(2.3 \%)\end{array}$ & $\begin{array}{l}276 \\
220\end{array}$ \\
\hline 46-80 & $\begin{array}{l}\text { Male } \\
\text { Female }\end{array}$ & $\begin{array}{ll}43 & (100 \%) \\
35 & (97.2 \%)\end{array}$ & $\begin{array}{l}0(0 \%) \\
1(2.8 \%)\end{array}$ & $\begin{array}{l}43 \\
36\end{array}$ \\
\hline Source & Age & Negative & Positive & Total \\
\hline Private lab & $\begin{array}{l}0-13 \\
14-45 \\
46-80 \\
\end{array}$ & $\begin{array}{l}0(0 \%) \\
164(96.5 \%) \\
29(96.7 \%) \\
\end{array}$ & $\begin{array}{l}0(0 \%) \\
6(3.5 \%) \\
1(3.3 \%) \\
\end{array}$ & $\begin{array}{l}0 \\
170 \\
30 \\
\end{array}$ \\
\hline $\begin{array}{l}\text { Children } \\
\text { hospital }\end{array}$ & $\begin{array}{l}0-13 \\
14-45 \\
46-80\end{array}$ & $\begin{array}{l}200(100 \%) \\
0(0 \%) \\
0(0 \%)\end{array}$ & $\begin{array}{l}0(0 \%) \\
0(0 \%) \\
0(0 \%)\end{array}$ & $\begin{array}{l}200 \\
0 \\
0\end{array}$ \\
\hline Red crescent & \begin{tabular}{l|l}
$0-13$ \\
$14-45$ \\
$46-80$ \\
\end{tabular} & $\begin{array}{l}2(100 \%) \\
183(100 \%) \\
15(100 \%)\end{array}$ & $\begin{array}{l}0(0 \%) \\
0(0 \%) \\
0(0 \%)\end{array}$ & $\begin{array}{l}2 \\
183 \\
15\end{array}$ \\
\hline $\begin{array}{l}\text { Center of } \\
\text { infectious } \\
\text { diseases }\end{array}$ & $\begin{array}{l}0-13 \\
14-45 \\
46-80 \\
\end{array}$ & $\begin{array}{l}20(87 \%) \\
137(95.8 \%) \\
34(100 \%)\end{array}$ & $\begin{array}{l}3(13 \%) \\
6(4.2 \%) \\
0(0 \%)\end{array}$ & $\begin{array}{l}23 \\
143 \\
34 \\
\end{array}$ \\
\hline Source & Gender & Negative & Positive & Total \\
\hline Private lab & $\begin{array}{l}\text { Male } \\
\text { Female }\end{array}$ & $\begin{array}{l}80(96.4 \%) \\
113(96.6 \%)\end{array}$ & $\begin{array}{l}3(3.6 \%) \\
4(3.4 \%)\end{array}$ & $\begin{array}{l}83 \\
117\end{array}$ \\
\hline $\begin{array}{l}\text { Children } \\
\text { hospital }\end{array}$ & $\begin{array}{l}\text { Male } \\
\text { Female }\end{array}$ & $\begin{array}{l}108(100 \%) \\
92(100 \%)\end{array}$ & $\begin{array}{l}0(0 \%) \\
0(0 \%)\end{array}$ & $\begin{array}{l}108 \\
92\end{array}$ \\
\hline Red crescent & $\begin{array}{l}\text { Male } \\
\text { Female }\end{array}$ & $\begin{array}{l}159(100 \%) \\
41(100 \%)\end{array}$ & $\begin{array}{l}0(0 \%) \\
0(0 \%) \\
\end{array}$ & $\begin{array}{l}159 \\
41 \\
\end{array}$ \\
\hline $\begin{array}{l}\text { Center of } \\
\text { infectious } \\
\text { diseases }\end{array}$ & $\begin{array}{l}\text { Male } \\
\text { Female }\end{array}$ & $\begin{array}{l}86(93.5 \%) \\
105(97.2 \%)\end{array}$ & $\begin{array}{l}6(6.5 \%) \\
3(2.8 \%)\end{array}$ & $\begin{array}{l}92 \\
108\end{array}$ \\
\hline
\end{tabular}

Another study in Saudi Arabia demonstrated that between 875 samples only four cases (two from Pakistan, one from India, and one from the Philippines) (Alzahrani et al., 2009), also our study showed one case was infected with HIV and hepatitis B virus in this case the confection because of the low immunity of HIV patients which susceptible to wide range of infections. A study concerned with the infection of $\mathrm{HBV}, \mathrm{HCV}$ viruses in HIV patients results show prevalence hepatitis $\mathrm{B}$ and hepatitis $\mathrm{C}$ infection to be significantly greater among HIV-infected patients than among blood donors. These observations confirm the high frequency of HIV-infected patient's exposure to these other viruses (Treitinger, et al., 2000). In addition, we found another case infected by both hepatitis $B$ and hepatitis $C$ virus this attributed to the route of infection. Regarding the source of samples we found in this study the infection 
with hepatitis $\mathrm{B}$ and hepatitis $\mathrm{C}$ virus was predominant in private laboratory with rate $(11 \%)$ in hepatitis $\mathrm{C}$ and $(18.5 \%)$ in HBV, while the infection with HIV showed a predominant rate in BCIDI (4.5\%).

In conclusion, reports revealed the presence of high prevalence of infection with Hepatitis B virus (HBV) and Hepatitis C virus (HCV) and Human Immunodeficiency virus (HIV) infection among the general population in Libya. We have this study to identify the extent of the problem at the national level, where the samples included 800 patients of all age groups. It turned out that the prevalence of HBV surface antigen (HBsAg) and HCV were $(6.4 \%)$ and $(5 \%)$ respectively and HIV virus was $(1.9 \%)$. The prevalence of $\mathrm{HCV}$ increased with age, in contrast the prevalence of HBsAg and HIV infection are common in young people. From this study it can be concluded that $\mathrm{HBV}, \mathrm{HCV}$, and HIV virus infection is a problem in Libya. A community-based study should be planned for targeting at risk and non-at risk subjects to investigate the extent of this problem and its impact on the community with an effort to develop preventive strategies.

\section{Acknowledgments}

We would like to express our thank to all people from the serology departments in the medical centers including Al Razi Medical Centre, Benghazi Centre of infectious diseases, Children hospital, and the medical Laboratory of Red crescent center for their assistance.

\section{References}

Abdelwahab, S.F., M. Hashem, I. Galal, M. Sobhy, T.S. Abdel-Ghaffar, G. Galal, N. Mikhail, S.S. El-Kamary, I. Waked and Strickland, G.T. 2013. Incidence of hepatitis $\mathrm{C}$ virus infection among Egyptian healthcare workers at high risk of infection. J. Clin. Virol., 57(1): 24-28.

Abudher, A., M.N. Esmeo, M. Sammud, A. Elzoukiand El-Gadi, O. 2008. Prevalence of hepatitis B,C and HIV infections in Libya: How big are the problems ?. Submitted to International AIDS Conference in Mexico City, 3-8.

Abu-Raddad, L.J., F. AyodejiAkala, I. Semini, G. Riedner, D. Wilson and Tawil, O. 2010. Characterizing the HIV/AIDS Epidemic in the Middle East and North Africa Time for Strategic Action. The World Bank.

Abu-Raddad, L.J., F. AyodejiAkala, I. Semini, G. Riedner, D. Wilson and Tawil, O. 2010. HIV/AIDS in MENA Assessment and Policy Recommendations. World Bank Quick Notes Series. 34.

Alter, M.J. 2007. Epidemiology of hepatitis C virus infection. World $J$. Gastroenterol., 13(17): 2436-2441.

Alzahrani, A.J., O.E. Obeid, A. Al-Ali and Imamwardi, B. 2009. Detection of hepatitis $\mathrm{C}$ virus and immunodeficiency virus in expatriates in Saudi Arabia by antigen-antibody combination assays. J. Infect. Develop. Countries, 3(3): 235-238.

Bagasra, O., M. Alsayari, R. Bullard-Dillard and Daw, M.A. 2007. Libyan HIV Outbreak How do we find the truth? Libyan J. Med., 2(2): 57-62.

Baha, W., A. Foullous, N. Dersi, T.P. Theythey, K. El alaoui, N. Nourichafi, B. Oukkache, F. Lazar, S. Benjelloun, M. Y. M. Ennaji, A. Elmalki, H. Mifdal and Bennani, A. 2013. Prevalence and risk factors of hepatitis $\mathrm{B}$ and $\mathrm{C}$ virus infections among the general population and blood donors in Morocco. BMC Public Health, 13: 50. 
Blumberg, B.S., H.J. Alter and Visnich, S. 1965. A new antigen in leukemia sera. Jama J., 191: 541-546.

Daw, M., and Dau, A. 2012. Hepatitis C in Arab world: a state of concern. Scientific World J., 719494.

Daw, M., and El-Bouzedi, A. 2014. Prevalence of hepatitis B and hepatitis $\mathrm{C}$ infection in Libya: results from a national population based survey. BMC Infectious Dis., 14: 17.

Daw, M., and Elkhammas, E. 2008. Libyan medical education time to move forward. Libyan J. Med., 3(1): 1-3.

Daw, M.A., M.A. Elkaber, A.M. Drah, M. M. Werfalli, A.A. Mihatand Siala, I. M. 2002. Prevalence of hepatitis C virus antibodies among different populations of relative and attributable risk. Saudi Med. J., 23: 1356-1360.

Elzouki, A.N., 2008. Hepatitis B infection in Libya: The magnitude of the problem. Libyan J. Infect. Dis., 2: 1-4.

Elzouki, N., N. Smeo, M. Sammud, O. Elahmer, M. Daw, A. Furarah, A. Abudher and Mohamed, K. 2013. Prevalence of hepatitis B and $\mathrm{C}$ virus infections and their related risk factors in Libya: a national seroepidemiological survey. Eastern Mediterranean Health J., 19: 7.

Habas, M., A. Khammajand Alhajarasi, A. 2009. The prevalence of hepatitis B and $\mathrm{C}$ of screened subjects in Tripoli [abstract]. $6^{\text {th }}$ Congress Maghrebin d'Hematologie, Congress National d'Hematologie. May,67.

Keeffe, E.B., 2007. Current issues in the management of hepatitis A and B. Gastroenteral and Endoscopy News. 5, 75-83.

Khmmaj, A., E. Habas, M. Azabiand Rayani, A. 2010. Frequency of hepatitis B, C, and HIV viruses among blood donors in Libya. Libyan J. Med., 5: 5333.
Kutrani, H., A. El-Gatit, A. Shekhteryea, Y. El-Gitait, O. Sudaniand Akoub, S. 2007. DemoFigureic factors influencing hepatitis B and C infection in Benghazi Libyan Arab Jamahiriya. Eastern Mediterranean Health J., 13: 85-97.

Lavanchy, D. 2004. Hepatitis B virus epidemiology, disease burden, treatment, and current and emerging prevention and control measures. $J$. Viral Hepatitis, 11(2): 97-107.

Lee, S.R., J. Peterson, P. Niven, C. Bahl, E. Page, R. Deleys, D. GiordanoSchmidt, D. Baggett and Green, G. 2001. Efficacy of a hepatitis $C$ virus core antigen enzyme-linked immunosorbent assay for the identification of 'window-phase' blood donations. Voxsanguinis, 80: 19-23.

Lok, A.S., and Mcmahon, B.J. 2007. Chronic hepatitis B. J. Hepatol., 45: 507-539.

Muhlberger, N., R. Schwarzer, B. Lettmeier, G. Sroczynski, S. Zeuzemand Siebert, U. 2009. HCV-related burden of disease in Europe: a systematic assessment of incidence, prevalence, morbidity, and mortality. BMC Public Health, 9: 34.

Shepard, C.W., L. Finelliand Alter, M.J. 2005. Global epidemiology of hepatitis $\mathrm{C}$ virus infection. The Lancet Infect. Dis., 5(9): 558-567.

Sievert, W., I. Altraif, H.A. Razavi, A. Abdo, E.A. Ahmed, A. Alomair, D. Almarapurkar, C.H. Chen, X. Dou, H. Elkhayat, M. Elshazly, G. Esmat, R. Guan, K.H. Han, K. Koike, A. Largen, G. Mccaughan, S. Mogawer, A. Monis, A. Nawaz, T. Piratvisuth, F. M. Sanai, A. I. Sharara, S. Sibbel, A. Sood, D. J. Suh, C. Wallace, K. Young and Negro, F. 2011. A systematic review of hepatitis $\mathrm{C}$ virus 
epidemiology in Asia. Australia and Egypt. Liver Int., 31(2): 61-80.

Sood, S., and Malvankar, S. 2010. Seroprevalence of Hepatitis B surface antigen antibodies to the Hepatitis $\mathrm{C}$ virus and human immunodeficiency virus in a hospital-based population in Jaipur Rajasthan. Indian $J$. Community, 35: 165-169.

Treitinger, A., C. Spada, L.A. Ferreira, M. S. Neto, M. Reis, J.C. Verdi, A.F. de Miranda, O.V. de Oliveira, M. Van der Sander Silveira and Abdalla, D.S. 2000. Hepatitis B and hepatitis C prevalence among blood donors and HIV-1 infected patients in Florianopolis-Brazil. The Brazilian J. Infect. Dis., 4(4): 192-196.
World Health Organization. 2009. Hepatitis C. [http://www.who.int/ mediacentre/ factsheets/fs 164/en].

World Health Organization. 2010. SixtyThird World Health Assembly. Viral Hepatitis. Report by the Secretariat. A63/15.

World Health Organization. Hepatitis C global prevalence (update). 1999. Weekly Epidemiological Record, 74: 425-427.

Zaied, A., A. Elneihoumand, and Elzouki, A. 2010. Routine screening for antiHIV antibodies hepatitis B surface antigen and anti-hepatitis $\mathrm{C}$ antibodies among general hospital in-patients. Jewish Morning J., 8-21.

\section{How to cite this article:}

Hanan I. Abdalla IL Fergani and Ismaeel H. Bozakouk. 2016. Detection and Identification of Hepatitis B, C and HIV in Benghazi city, Libya. Int.J.Curr.Microbiol.App.Sci. 5(10): 330-341. doi: http://dx.doi.org/10.20546/ijcmas.2016.510.037 